\title{
Charakterystyka e-learningu jako instrumentu wspierającego aktywności HR w adaptowaniu pracowników
}

\author{
MARIUSZ ANDREASIK \\ Szkoła Główna Handlowa w Warszawie
}

\begin{abstract}
Adaptacja jako jeden z elementów procesu rekrutacji jest ważnym elementem wprowadzenia pracownika do nowej organizacji. W artykule przeprowadzono analizę zastosowania nowych technologii, jak e-learning, wykorzystywanych w przedsiębiorstwach jako element transformacji cyfrowej oraz odpowiedź na oczekiwania nowych generacji pracowników.
\end{abstract}

Słowa kluczowe: e-learning, adaptacja, zarządzanie zasobami ludzkimi

Kody klasyfikacji JEL: M12, M53, M54

\section{Wprowadzenie}

Jednym z większych problemów w przedsiębiorstwach jest wysoki wskaźnik fluktuacji pracowników. Fluktuacja kadr to wymiana składu zatrudnionych osób: dobrowolna rezygnacja lub zwalnianie pracowników wraz z koniecznością zastąpienia ich nowymi kandydatami. Według raportu portalu ManaHR ogólnopolskie wskaźniki 
fluktuacji w polskich przedsiębiorstwach kształtowały się na poziomie 15\% w 2019 i 2018 r. oraz 16\% w 2017 r. Według Vien (2007), powołującej się na Society of Human Resources Management, koszt rotacji na jednym stanowisku pracy wynosi przeciętnie od 50\% do 60\% rocznego wynagrodzenia. Według Boushey i Glynn (2012) koszt ten zależy od poziomu zarobków pracowników i waha się pomiędzy $16 \%$ a $20 \%$ rocznego wynagrodzenia. Na koszt rotacji składają się koszty odejścia pracownika i jego zastąpienia - związane $\mathrm{z}$ wdrożeniem nowego pracownika, oraz koszty utraconych korzyści. Według Kubicy (2010) jednym z czynników rezygnacji pracownika jest rozczarowanie zakresem obowiązków i warunkami pracy w nowej organizacji.

Okres wdrażania nowego pracownika jest definiowany w polskiej literaturze przedmiotu jako adaptacja, a w anglojęzycznej literaturze jako onboarding. Ziębicki i Mikuła (2003) twierdzą, że brak poprawnego wprowadzenia w zakres obowiązków pracownika może skutkować przyjęciem przez niego niepożądanych postaw w późniejszej karierze zawodowej. Według Żarczyńskiej-Dobiesz (2008) to w tym czasie pracownicy powinni się przystosować do firmy, nowej roli i stanowiska pracy, współpracowników, przełożonego oraz materialnych warunków pracy. Kubica (2010) uważa, że objęcie pracowników systematycznym, planowanym i przemyślanym procesem adaptacji zwiększa aż o $69 \%$ szansę na to, że pozostaną oni w firmie przez co najmniej trzy lata. Iwańczuk (2008) podkreśla, że pracownicy objęci procesem adaptacji osiągają dwa miesiące wcześniej pełną efektywność wykonywanych zadań i są bardziej zaangażowani w pracę.

Z uwagi na wysokie koszty fluktuacji pracowników oraz wpływ procesu adaptacji na zmniejszenie zakresu tego zjawiska, temat wydaje się bardzo interesujący z punktu widzenia badań naukowych. Istnieje luka badawcza związana $z$ tematem wpływu coraz szerszego wykorzystania systemów platform e-learningowych wspierających obsługę procesu adaptacji nowych pracowników na fluktuację pracowników. Rynek rozwiązań informatycznych dla działów HR (Human Resources), ZZL (Zarządzania Zasobami Ludzkimi) rośnie. Wraz z postępującymi procesami informatyzacji, digitalizacji średnich i dużych przedsiębiorstw zastosowanie ich w rozwoju pracowników, szkoleniach i w adaptacji pracowników się poszerza i ma coraz większe znaczenie. Wykorzystanie e-learningu w przedsiębiorstwach szczególnie przyśpieszyło w czasach pandemii COVID-19, kiedy wiele branż zdecydowało się na pełną pracę zdalną. Nie wiadomo, czy pracownicy z niej w pełni wrócą, gdyż wyniki wskaźniki efektywności czy zysków nie spadły. W tym trybie większość rekrutacji oraz procesów adaptacji odbywało się zdalnie. Rozmowy kwalifikacyjne przeprowadzano z wykorzystaniem narzędzi do wideokonferencji. Na platformach e-learningowych testowano wiedze pracowników, przygotowywano programy adaptacyjne, które zawierały informacje wprowadzające do firmy. W związku z tymi trendami oraz wyjątkową sytuacją interesujące jest zbadanie, w jakim stopniu zastosowanie e-learningu wpływa na proces 
adaptacji nowych pracowników w średnich i dużych przedsiębiorstwach w Polsce. Jest to zagadnienie, które powinno być przeanalizowane i zbadane w planowanej pracy badawczej.

\section{Adaptacja nowych pracowników}

Według Schwan (2018) adaptacja nowych pracowników jest ostatnią fazą procesu selekcji i rekrutacji. Polega na wprowadzeniu pracownika do organizacji i wdrożeniu go do zadań. Jest też traktowana jako złożony proces ekonomiczny, socjologiczny i psychologiczny. Kazenas (2012) podkreśla, że celem adaptacji jest jak najszybsze i bezkonfliktowe włączenie nowego pracownika do organizacji oraz jej życia społecznego. Kowalska (2018) komentuje, że adaptacja pracownika do nowej roli organizacyjnej jest niedocenionym obszarem zarządzania zasobami ludzkimi w przedsiębiorstwie. Mikuła i Ziębicki (2003) określają, że jedną z głównych faz procesu zarządzania zasobami ludzkimi jest wprowadzenie nowo przyjętego pracownika do pracy. Bezkonfliktowe wdrożenie go do obowiązków, przyjęcie, przystosowanie do nowej roli zawodowej ma w konsekwencji istotny wpływ na efektywność wyników i osiągnięcia (Jamka, 2001). Za TendertHut (2018) „wdrożenie” to najczęściej stosowane określenie momentu objęcia przez pracownika nowego stanowiska (onboarding).

W języku angielskim on board oznacza "na pokład” i jest stosowane w związku $\mathrm{z}$ wejściem nowej osoby w strukturę firmy. Określenie to zostało zaadaptowane w branży zasobów ludzkich oraz usług i produktów wspierających ten proces, jak e-learning. Według Steina i Christiansen (2010) to w wyniku badania Amerykańskiego Towarzystwa Szkoleń i Rozwoju z 2000 r. uznano onboarding za nowo powstającą subfunkcję zarządzania zasobami ludzkimi.

Znaczące jest to, że w literaturze naukowej nie stosuje się sformułowania onboarding, które jest powszechne wśród firm dostarczających rozwiązania informatyczne i e-learningowe wspierające ten proces. Niemniej naukowym stwierdzeniem pozostaje adaptacja i to pojęcie będzie wykorzystywane w niniejszym artykule. Król i Ludwiczyński (2014) zwracają uwagę na fakt, że adaptacja jest procesem złożonym i wielowymiarowym, którego powodzenie zależy zarówno od pracownika, jak i działań podjętych przez organizację. Listwan (2006) twierdzi, że adaptacja pracownika w firmie ma zarówno funkcję społeczną, polegającą na poznaniu przez pracownika kultury organizacyjnej, jak i organizacyjną, skoncentrowaną na wprowadzeniu pracownika w nowe miejsce pracy. Gembalska-Kwiecień i Żurakowski (2016) słusznie zauważają, że osoba nowo zatrudniona nie będzie od razu samodzielnym i efektywnie pracującym członkiem zespołu. Dlatego podkreślają, że okres adaptacji jest bardzo ważny w dalszym rozwoju i kształtowaniu nowo przyjętych pracowników. 


\section{Organizacja i zakres adaptacji nowego pracownika}

Według Zaleśnej (2015) adaptacja powinna być prowadzona w celu najsprawniejszego wprowadzenia pracownika, aby zakład pracy jak najszybciej mógł się wzbogacić jego wiedzą i umiejętnościami. Autorka ta twierdzi, że przekazanie istotnych informacji o firmie jest jednym z czynników udanej adaptacji pracownika w nowej pracy. Syper-Jędrzejak (2013) zaobserwowała, że adaptacja rozumiana jest również jako wprowadzenie do organizacji, odbywa się za pomocą wielu instrumentów, podmiotów, ze szczególnym uwzględnieniem roli bezpośredniego przełożonego, który często zostaje opiekunem pracownika lub, jak określa to Zabiegliński (2011), mentorem. W jego rolę może się również wcielić doświadczony pracownik, z którym uzgadniany jest harmonogram adaptacji. Kaźmierczak (2017) uznaje, że adaptacja jest jednym z najważniejszych elementów procesu zarządzania zasobami ludzkimi, a odpowiednio przeprowadzona dostarcza wymiernych korzyści obu stronom: pracownikowi i organizacji. Zdaniem Oleksyna (2006) celem adaptacji jest szybka i bezinwazyjna aklimatyzacja jednostki do nowego środowiska pracy, ale również odpowiednie przygotowanie zespołu na dołączenie nowego członka. Kaźmierczak (2017) określa zakres adaptacji jako czas na zapoznanie się ze strategią, misją, wizją, historią firmy oraz stosunkami interpersonalnymi panującymi w grupach nieformalnych, co jest spójne ze zdaniem Ziębickiego (2003), który tę listę uzupełnia o podstawowe dane organizacyjno-ekonomiczne (charakterystyka działalności, pozycja na rynku, struktura własnościowa, główni klienci i partnerzy, generalna organizacja firmy, struktura i powiązania z filiami). Bańka (2002) uważa, że istotne jest opracowanie konkretnego programu wprowadzenia do pracy przez komórkę kadrową. Bauer (2010), używając określenia onboarding new employees, wskazuje, że wdrażanie podwładnego składa się z czterech etapów związanych z wprowadzeniem pracownika w procedury obowiązujące w firmie: dostarczenie informacji, wyznaczenie celów i zadań, prezentacja kultury organizacyjnej oraz zadbanie o integrację z resztą zespołu. Badania prowadzone przez Hirsch (2017) wykazują, że aż 69\% podwładnych, którzy przeszli przez odpowiedni program onboardingowy, chętniej pozostaje w organizacji przez minimum trzy lata. Według Zaleśnej (2015) adaptacja powinna mieć charakter zorganizowany. Żarczyńska-Dobiesz (2008) podziela ten punkt widzenia, stwierdzając, że proces adaptacji może mieć charakter instytucjonalny lub indywidualny. W przypadku charakteru instytucjonalnego - firma „odgórnie” określa spójny, jednolity proces wdrażania każdego nowego pracownika. W podejściu indywidualnym kolejne kroki dopasowywane są do cech i potrzeb danej osoby (związanych m.in. z dotychczasowym doświadczeniem zawodowym lub jego brakiem). W obu przypadkach role i odpowiedzialność w procesie adaptacji są dokładnie określone - różny jest tylko 
proces postępowania (bardziej lub mniej elastyczny). Ludwiczyński (2006) podkreśla, że dobrze przeprowadzona adaptacja pozwala pracownikowi sprawnie działać zarówno w wymiarze zawodowym (realizacja zadań), jak i społecznym (jakość współpracy). Bugaj (2012), badając procesy zarządzania zasobami ludzkimi w służbie zdrowia, przedstawia ciekawy punkt widzenia na adaptację: definicyjnie adaptacja w ujęciu biologicznym to przystosowanie się organizmu przez zmianę struktury lub funkcji do życia w nowych dla niego, trwale zmienionych warunkach bytowych lub zewnętrznego stresu. W ujęciu psychologicznym to przystosowanie, dostosowanie zachowania do wymogów sytuacji środowiska. Składają się na nie procesy akomodacji i asymilacji. Autorka wnioskuje z tego, że adaptacją można nazwać proces przystosowania się pracownika do funkcjonowania w zmienionym otoczeniu lub całkowitą bądź częściową zmianę, polegającą na przyjęciu wartości i norm, sposobów definiowania sytuacji oraz wzorów zachowań obowiązujących w tym nowym otoczeniu.

Tabela 1. Definicje adaptacji

\begin{tabular}{|l|l|}
\hline \multicolumn{1}{|c|}{ Źródło } & \multicolumn{1}{c|}{ Definicja adaptacji } \\
\hline $\begin{array}{l}\text { Schwan, } \\
\text { Seipel (1994) }\end{array}$ & $\begin{array}{l}\text { Adaptacja nowych pracowników polega na wprowadzeniu pracownika do } \\
\text { organizacji i wdrożeniu go do zadań }\end{array}$ \\
\hline $\begin{array}{l}\text { Marciniak } \\
\text { (1997) }\end{array}$ & $\begin{array}{l}\text { Celem procesu adaptacji nowo przyjętych pracowników jest możliwie jak } \\
\text { najszybsze i zarazem bezkonfliktowe włączenie pracownika do organizacji, } \\
\text { polegające przede wszystkim na przekazaniu wzorów zachowań wymaganych od } \\
\text { pracownika w przyszłości } \\
\text { Marciniak wymienia cztery etapy wprowadzenia pracownika do pracy: ogólne } \\
\text { wprowadzenie do pracy, określenie i przekazywanie zadań związanych z danym } \\
\text { stanowiskiem, wdrożenie do konkretnych zadań na stanowisku pracy oraz } \\
\text { wstępną ocenę przydatności zawodowej }\end{array}$ \\
\hline $\begin{array}{l}\text { Pocztowski } \\
(2003)\end{array}$ & $\begin{array}{l}\text { Wymiar zawodowy adaptacji związany jest z przystosowaniem pracownika do } \\
\text { treści i warunków pracy (zakres zadań na stanowisku i powiązanie z innymi } \\
\text { stanowiskami, struktura podziału pracy w firmie, stosowana technologia, systemy } \\
\text { zarządzania, organizacja pracy czy możliwości rozwoju) } \\
\text { Wymiar społeczny obejmuje poziom firmy (akceptacja celów, misji i podstawowych } \\
\text { wartości obowiązujących w organizacji) oraz poziom zespołu (akceptacja norm } \\
\text { i zasad panujących w danym zespole, styl kierowania przyjęty przez przełożonego, } \\
\text { reguły kontaktów społecznych i atmosfery pracy) }\end{array}$ \\
\hline $\begin{array}{l}\text { Mikuła, } \\
\text { (2003) }\end{array}$ & $\begin{array}{l}\text { Proces adaptacji sprowadza się w istocie do przekazania nowemu pracownikowi } \\
\text { wszystkich niezbędnych informacji organizacyjnych pozwalających mu } \\
\text { na efektywne realizowanie powierzanych zadań }\end{array}$ \\
\hline Bauer (2010) & $\begin{array}{l}\text { Cztery główne etapy wdrażania podwładnego (tzw. 4 C): } \\
\text { compliance - dostarczenie pracownikowi informacji dotyczących procedur } \\
\text { obowiązujących w firmie } \\
\text { clarification - wyznaczenie celów i zadań podwładnemu } \\
\text { culture - zaprezentowanie kultury organizacyjnej przedsiębiorstwa zarówno } \\
\text { w kwestiach formalnych, jak i nieformalnych }\end{array}$ \\
\hline connection - dbałość o zintegrowanie pracownika z resztą zespołu
\end{tabular}


cd. tabeli 1

\begin{tabular}{|c|c|}
\hline Źródło & Definicja adaptacji \\
\hline $\begin{array}{l}\text { Ciekanowski } \\
(2012)\end{array}$ & $\begin{array}{l}\text { Trzy kluczowe etapy adaptacji: } \\
\text { - przygotowanie miejsca pracy przed przyjściem nowego pracownika, } \\
\text { opracowanie dokumentacji, doprecyzowanie zakresu zadań } \\
\text { - szczegółowe zaplanowanie pierwszego dnia pracy, kiedy pracownik powinien } \\
\text { otrzymać szczegółowe informacje na temat firmy i swojego stanowiska pracy, } \\
\text { przejść szkolenia przygotowawcze i obowiązkowe (BHP) } \\
\text { - praktyczne poznanie zasad działania firmy, jej kultury, zwyczajów, rozpoczęcie } \\
\text { realizacji zadań na stanowisku, monitorowanie jakości i efektywności pracy } \\
\text { przez przełożonego }\end{array}$ \\
\hline $\begin{array}{l}\text { Syper- } \\
\text {-Jędrzejak } \\
(2013)\end{array}$ & $\begin{array}{l}\text { Adaptacja w zasadzie polega na wprowadzeniu pracownika do organizacji } \\
\text { i wdrożeniu go do zadań wykonywanych na konkretnym stanowisku. Proces } \\
\text { adaptacji ma cztery podstawowe cele: } \\
\text { - ułatwienie pierwszych etapów pracy, kiedy pracownikowi wszystko wydaje się } \\
\text { obce, nieznane i skomplikowane } \\
\text { - stosunkowo szybkie wykształcenie u nowo przyjętych przyjaznej postawy } \\
\text { wobec przedsiębiorstwa, która w domyśle zaowocuje skłonnością do pozostania } \\
\text { w organizacji } \\
\text { - uzyskanie w jak najkrótszym czasie efektywnych wyników pracy nowego } \\
\text { pracownika }\end{array}$ \\
\hline $\begin{array}{l}\text { Kwiecień, } \\
\text { Żurakowski } \\
\text { (2016) }\end{array}$ & $\begin{array}{l}\text { Adaptacja zawodowa nowo zatrudnionego pracownika na stanowisku pracy } \\
\text { rozumiana jest jako: } \\
\text { - czas pozwalający nowo przyjętemu pracownikowi na zintegrowanie się } \\
\text { - okres wdrażania się pracownika w całokształt czynności zawodowych } \\
\text { na stanowisku pracy } \\
\text { - zespół celowych działań tworzących sprzyjające warunki umożliwiające nowo } \\
\text { przyjętym pracownikom uzyskanie wymaganych i oczekiwanych efektów pracy, } \\
\text { przy jednoczesnym zagwarantowaniu bezpieczeństwa i higieny warunków pracy }\end{array}$ \\
\hline
\end{tabular}

Źródło: opracowanie własne.

\section{Adaptacja częścią większego procesu}

Kałużny (2018) zauważa, że proces adaptacyjny dla nowego pracownika rozpoczyna się od rekrutacji i selekcji. Po zaakceptowaniu oferty pracy kandydata i zatrudnieniu go na odpowiednim stanowisku wchodzi on do organizacji. Z chwilą zatrudnienia rozpoczyna się pierwszy z etapów procesu adaptacyjnego: identyfikacja i zarejestrowanie zmiany. Według Ratajczak (2007) rekrutacja pracowników, czyli przyjmowanie ich do pracy, to jedno z podstawowych zadań polityki personalnej każdej organizacji. Rekrutacja odnosi się do nowych pracowników i obejmuje wszystkie czynności wyspecjalizowanych działów kadrowych, od zamieszczenia ogłoszenia do przyjęcia do pracy. Według Karney (2007) etapem rekrutacji jest również selekcja. Etap ten wyróżnia się całokształtem działań podejmowanych w celu wyboru pracownika spośród grupy kandydatów na dane stanowisko, za pomocą dostępnych metod, 
technik i narzędzi. Najczęściej doboru dokonuje się na podstawie informacji zawartych w życiorysie (CV), liście motywacyjnym, a także dodatkowych dokumentów, takich jak: dyplomy ukończonych uczelni, referencje, opinie, świadectwa pracy oraz inne dowody kwalifikacji i doświadczenia zawodowego. Według Woźniak (2013) rekrutacja w zarządzaniu zasobami ludzkimi klasyfikowana jest jako jeden z czterech etapów procesu naboru pracowników, na który składają się następujące działania: planowanie kadr, rekrutacja, selekcja i adaptacja. W związku z taką charakterystyką tego procesu i traktowaniem adaptacji jako finalnego etapu rekrutacji warto rozważyć wpływ poszczególnych etapów na proces adaptacji. Nieważne, jak dobrze będzie opracowany i przeprowadzony proces adaptacji, błędy popełnione na wcześniejszych etapach mogą wpływać na to, czy pracownik zostanie dłużej w firmie, czy będzie zadowolony, czy stanie się dobrym pracownikiem i członkiem zespołu.

\section{Rysunek 1. Etapy procesu rekrutacji i wdrożenia pracowników}
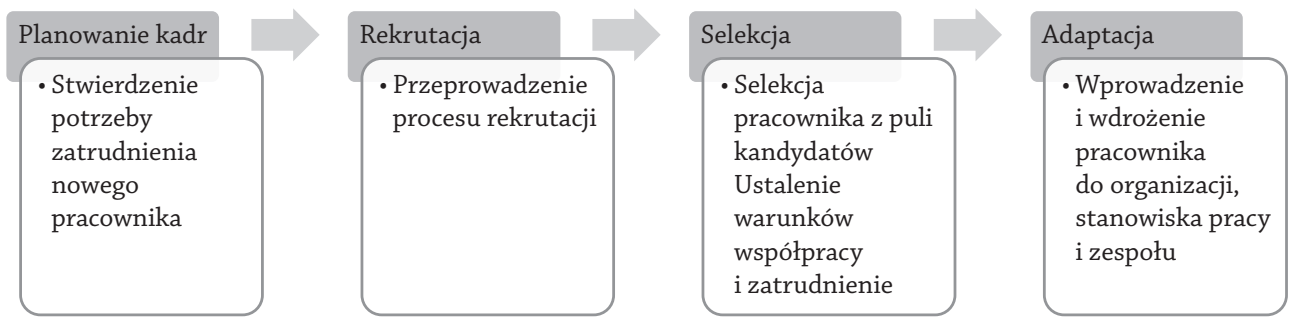

Źródło: opracowanie własne.

\section{Rola e-learningu w adaptacji pracowników}

W trakcie adaptacji wykorzystywane są różne metody. Zaleśna (2005) uważa, że podczas tego procesu bardzo aktywny powinien być pracodawca. Informacje powinien przekazywać bezpośrednio przełożony (właściciel firmy), zatrudniony w firmie menedżer, wyznaczony do tego zadania opiekun. Źródłem informacji mogą być również współpracownicy. Dla nowego pracownika przydatne są biuletyny, informatory firmy. Biorąc to pod uwagę, średnie i duże przedsiębiorstwa zaczęły wykorzystywać nowe technologie do dzielenia się wiedzą z nowymi pracownikami.

Kowalska (2018) przedstawia wdrożenie pracownika z wykorzystaniem platformy gamifikacyjnej opartej na scenariuszu gier. Według niej cyfrowa transformacja jest kluczowym czynnikiem dla rozwoju przedsiębiorstwa, a zastosowanie grywalizacji jako subtelnego czynnika motywacyjnego może znacznie zwiększyć wydajność pracowników. Przeprowadzone badania dotyczące implementacji grywalizacji w procesie adaptacji przedstawiciela handlowego w polskiej firmie z sektora spożywczego wykazały, 
że przeprowadzony projekt $\mathrm{z}$ wykorzystaniem gamifikacji (platformy dostępnej online z testami wiedzy, informacjami do zapoznania się) zwiększył wiedzę pracowników. Zostało to potwierdzone za pomocą pre i post testów. Jest to jeden z przykładów wykorzystania nowych technologii przez przedsiębiorstwa w adaptacji pracowników.

Niniejszy artykuł ma na celu przybliżenie tematyki e-learningu w procesie adaptacji nowych pracowników. Wpływ na ten proces powinien zostać zbadany podczas projektu badawczego. Dlatego tak ważne jest zdefiniowanie i określenie, co jest rozumiane jako e-learning.

\section{Wprowadzenie do e-learningu}

Sanocki i Wurst (2021) definiują e-learning jako nauczanie poprzez nowoczesne technologie i narzędzia elektroniczne, uzupełniające za pomocą komputerów, smartfonów, tabletów i Internetu tradycyjny proces nauczania. Woźniak (2012) definiuje również e-learning korporacyjny jako metodę szkoleniową w przedsiębiorstwach, używaną najczęściej do szkoleń obowiązkowych, takich jak BHP i ochrona przeciwpożarowa, a także zmian w regulaminach firmy i przepisach prawnych. Frączek (2015) wskazuje, że e-learning jest powszechnie rozumiany jako celowe, zamierzone wykorzystanie informacji w sieci oraz technologii komunikacyjnych (technologii informacyjnych i komunikacyjnych - TIK, Information and Communication Technologies - ICT), zwanych zamiennie technologiami informacyjno-telekomunikacyjnymi, technikami informacyjnymi lub teleinformatycznymi w procesie kształcenia. Orczykowska (2006) określa e-learning jako metodę nauczania na odległość, poza bazą edukacyjną (distance learning), oraz jako silnie rozwijającą się metodę edukacyjną, skutecznie wspomagającą naukę tradycyjnego szkolnictwa oraz biznesu. Porządkuje ona również fakt, że nauczanie na odległość (distance education), czyli nauka poza bazą wykładową, w dowolnym czasie, bez bezpośredniego nadzoru, nie jest zjawiskiem nowym. Ta metoda została wynaleziona prawie 100 lat temu. Na początku polegała na wymianie korespondencji pocztowej pomiędzy odbiorcą, uczniem a instytucją prowadzącą kurs. Ten sposób, wzbogacony o płyty, kasety wideo i inne „wspomagacze” multimedialne jest popularny do dzisiaj. Kiliszewski (2003) wskazuje cechy, które znacząco wpłynęły na sukces e-learningu, główną z nich jest elastyczność nauczania, którą należy rozumieć jako:

- naukę w dowolnym miejscu i czasie,

- dowolną liczebność grupy,

- indywidualizację nauczania,

- wychodzenie naprzeciw potrzebom ucznia,

- aktualność szkoleń. 
Według Smala (2009) wprowadzenie systemu zdalnego nauczania daje szansę zdobycia wiedzy bez konieczności dojeżdżania na zajęcia. Poprzez udostępnianie i wykorzystywanie szerokiego zasobu materiałów dydaktycznych, e-edukacja sięga do nowych technologii przekazu oraz pozwala na istotną redukcję kosztów szkolenia. Clarke (2007) porządkuje definicję e-learningu (w języku polskim określanego terminami: nauka na odległość, kształcenie na odległość, zdalna edukacja, nauczanie elektroniczne, e-nauczanie, nauka online, nauczanie hybrydowe) jako wiele różnych metod nauczania, których wspólną cechą jest wykorzystywanie technik informacyjnych. Porządkuje również anglojęzyczne i polskie sformułowania wokół tego tematu:

\begin{tabular}{|l|l|}
\hline \multicolumn{1}{|c|}{ Termin anglojęzyczny } & \multicolumn{1}{c|}{ Termin polski } \\
\hline Blended learning & $\begin{array}{l}\text { Nauka metodami łączonymi (tj. zajęcia stacjonarne } \\
\text { z trenerem, wykładowcą oraz materiały dostępne online do } \\
\text { nauki własnej) }\end{array}$ \\
\hline Computer mediated communication & Komunikacja za pośrednictwem komputera \\
\hline Computer mediated learning & Nauka za pośrednictwem komputera \\
\hline Computer-based learning & Nauka za pomocą komputera \\
\hline Distributed learning & Nauczanie rozproszone \\
\hline Interactive learning materials & Interaktywne materiały dydaktyczne \\
\hline Learning objects & $\begin{array}{l}\text { Obiekty uczące (tj. materiały udostępnione do nauki we } \\
\text { własnym zakresie, wymagające interakcji jak ćwiczenia, testy, } \\
\text { quizy wiedzy) }\end{array}$ \\
\hline Learning resources & $\begin{array}{l}\text { Zasoby dydaktyczne (tj. materiały udostępnione do nauki we } \\
\text { własnym zakresie) }\end{array}$ \\
\hline Online learning & Nauka online - za pośrednictwem sieci \\
\hline Web-based training & Szkolenia internetowe \\
\hline
\end{tabular}

Źródło: opracowanie własne.

\section{Narzędzia i metody e-learningowe}

E-learning to metoda nauczania, która posługuje się wieloma narzędziami. Jednym z ważniejszych wykorzystywanych w średnich i dużych przedsiębiorstwach są kursy e-learningowe (za: Clarke, 2007 - web-based training, tj. szkolenia internetowe), nazywane zamiennie szkoleniami e-learningowymi. Hyla (2005) proponuje następującą definicję kursu e-learningowego: „jest to podporządkowany określonemu celowi szkoleniowemu elektroniczny zasób treści, przeznaczony do samodzielnego wykorzystania i wyposażony w elementy nawigacyjne". Orczykowska (2006) 
wskazuje na potrzebę dookreślenia „treści szkoleniowej”, gdyż jest to pojemne określenie i zawiera m.in.:

- zapisy w formie elektronicznej - e-booki, instrukcje, dokumenty i inne,

- prezentacje, np. w formacie PowerPoint,

- inne zestawienia tekstowe i liczbowe (np. w formacie Word, Exel),

- nagrania dźwiękowe i filmy edukacyjne,

- zasoby wiedzy z baz eksperckich, z forów internetowych dla określonych grup użytkowników, informacje i doświadczenia wymieniane w czasie czatów edukacyjnych,

- różnorodne elementy multimedialne - gry interaktywne, testy, prace zespołowe wykonywane przez użytkowników w sieci,

- wideokonferencje i konferencje internetowe,

- wszelkie inne metody.

\section{Rosnące znaczenie i zastosowanie e-learningu}

Według raportu Linkedin (2020) Workplace Learning Report 57\% profesjonalistów zajmujących się nauką i rozwojem w przedsiębiorstwach wyda więcej środków na e-learning, a będzie to związane z przeniesieniem środków ze szkoleń stacjonarnych (38\% spadek w wydatkach). W raporcie Linkedin (2020) 94\% pracowników wskazało, że możliwość nauki i rozwoju w trakcie pracy jest dużym benefitem. Według raportu Docebo (2019) E-learning trends następuje wzrost chęci pracowników do nauki w pracy $-68 \%$, którzy chcą się uczyć we własnym tempie - 58\%, co wpisuje się w metodę e-learningu, czyli dostarczania wiedzy w formie możliwej do odtworzenia w dowolnym momencie i miejscu. Spośród menedżerów 90\% uznało, że nauka i rozwój to kluczowy benefit dla pracowników od organizacji, a $81 \%$ uważa, że rozwój talentów to kluczowy priorytet w firmach. W raporcie wskazano również rosnącą wśród organizacji i pracowników potrzebę dostępu do platform do nauki i dzielenia się wiedzą, ze względu na rosnący trend pracy zdalnej. Coraz więcej osób się przemieszcza, podróżuje, pracuje z różnych lokalizacji (wg raportu Global Workplace Analytics, 2019 - w latach 2005-2019 liczba osób pracujących zdalnie wzrosła o 140\%, a tylko pomiędzy 2017 a 2018 r. o 22\%).

Szkolenia e-learningowe są udostępniane użytkownikom w średnich i dużych przedsiębiorstwach za pośrednictwem platform e-learningowych. Clarke (2007) określa je jako systemy do zarządzania nauczaniem (procesem nauczania), które są częścią systemów do zarządzania kursami obejmującego elementy umożliwiające naukę online. Są one określane skrótami VLE (Virtual Learning Environments) lub LMS (Learning Management Systems). Plebańska i Kopciał (2013) scharakteryzowali 
platformę e-learningową jako narzędzie zarządzania wiedzą. Przedstawili dwa modele - w pierwszym platforma edukacyjna to system przeznaczony do realizacji procesów kształcenia w organizacji. Platforma odgrywa w tym systemie kluczową rolę, konsolidując wszelkiego rodzaju materiały szkoleniowe, nazywane często biblioteką produktów rozwojowych. W drugim modelu prezentują platformę e-learningową nie tylko jako system zapewniający szeroko pojęty rozwój pracowniczy, ale również jako sposób testowania wiedzy i umiejętności pracowników. W ramach wdrożenia w organizacji tego modelu pracownicy mogą rozwiązywać na platformie e-learningowej różnego typu testy, np. sprawdzające wiedzę z dowolnej dziedziny, kompetencyjne, stanowiskowe, egzaminy certyfikacyjne, pretesty czy testy po szkoleniu.

Żołędziewski (2011) zauważa, że e-learning, określany również mianem szkolenia elektronicznego, nie jest jedynie modną nowinką techniczną, którą przedsiębiorstwa i organizacje wdrażają dla uatrakcyjnienia przeprowadzanych szkoleń. Edukacja wspierana przez technologie informatyczne odgrywa istotną rolę w strategiach rozwoju gospodarki wielu potęg gospodarczych świata. Według Abramek (2003) platforma e-learningowa ułatwia rozpoznanie struktury i funkcjonowania firmy, stanowi płaszczyznę komunikacji i współpracy w firmie, sprzyja integracji pracowników, ułatwia współdzielenie i budowanie wiedzy firmy oraz pomaga w procesie adaptacji nowych pracowników.

Ostatni aspekt powinien zostać bliżej zbadany i przeanalizowany podczas planowanego projektu badawczego. W jakim stopniu zastosowanie e-learningu wpływa na proces adaptacji nowych pracowników w przedsiębiorstwach? Dotychczasowa analiza literatury wykazała pojedyncze przykłady wykorzystania wybranych narzędzi e-learningowych - jak grywalizacja, która ze względu na swoją cenę dostępna jest tylko dla zasobnych przedsiębiorstw, głównie korporacji.

Biorąc pod uwagę wzrost zastosowania e-learningu w przedsiębiorstwach, można uznać, że jest on ważnym zagadnieniem naukowym. W związku z obecną sytuacją liczba przedsiębiorstw umożliwiających pracownikom pracę zdalną znacznie wzrasta. Dzięki dostępowi online do systemów pracownicy wciąż mogą pracować i się rozwijać, a rola i potrzeba systemów e-learningowych będzie się sukcesywnie zwiększać. Zainteresowanie firm i instytucji e-learningiem jest podyktowane zmieniającymi się trendami w rozwoju pracowników. Według raportu Linkedin 2019 Workplace Learning Report firmy coraz więcej inwestują w programy rozwojowe oraz talentowe. Nakłady wzrosły o $27 \%$ w 2017 r., 35\% w 2018 r. oraz $43 \%$ w 2019 r., a jedynie $27 \%$ badanych wskazało, że budżet ogranicza ich w lepszym rozwoju kadr. Według raportu Coursera Global Skills Index 2019 dwie trzecie światowej populacji ma niskie umiejętności w krytycznych obszarach, a technologia przyśpiesza w dużo szybszym tempie, niż ludzie są w stanie ją zaadaptować. Według Coursera jest to główne wyzwanie dla firm oraz krajów, które muszą inwestować w rozwój bardzo dużej liczby osób 
i wykorzystać nowe technologie do nauczania zdalnego (e-learning). Trendy rynkowe pokazują, że coraz więcej firm i krajów docenia rolę e-learningu w szkoleniach i edukacji. Wzrost zapotrzebowania na rozwiązania e-learningowe jest również podyktowany oczekiwaniami nowych generacji wchodzących na rynek. Według raportu Docebo (2017) Elearning Market Trends And Forecast 2017-2021 dla tzw. milenialsów szkolenia i rozwój są najważniejszym benefitem, jaki może zaoferować pracodawca - 22\% wskazało ten obszar jako numer jeden. Celem departamentów szkoleń i rozwoju według raportu Docebo (2017) jest w 90\% wzrost produktywności i efektywności, w 69\% przekształcanie wiedzy w kompetencje, w 67\% edukacja i rozwój pracowników. Zgodnie z tym raportem $64 \%$ użytkowników e-learningu uważa dostęp do wiedzy za pomocą urządzeń mobilnych za konieczność. Ten sam raport pokazuje, że 58\% pracowników preferuje naukę we własnym tempie, $87 \%$ pracowników uznaje społeczne dzielenie się wiedzą za konieczne, 80\% menedżerów uważa, że efektywne szkolenia pracowników są krytycznym czynnikiem wpływającym na realizację celów oraz terminów, co przekłada się m.in. na o 22\% szybsze wdrożenia produktów i ofert oraz obniżenie czasu produkcji materiałów sprzedażowych o 35\%, 92\% dyrektorów uważa, że umiejętności miękkie są równie ważne, jeśli nie ważniejsze, niż umiejętności techniczne.

Istotny jest również moment przeprowadzenia analizy i badań naukowych. Po ponad roku panującej globalnej pandemii spowodowanej COVID-19 można zaobserwować szersze i intensywniejsze wykorzystanie technologii do nauki, edukacji i szkoleń. Przykładowo Linux Foundation wg Bayern (2020) zanotowała wzrost zapisów na kursy e-learningowe o 40\%, platforma e-learningowa Docebo odnotowała wzrost aktywności użytkowników o 18,5\%. Iqbal (2020) stwierdza wzrosty w wykorzystaniu platformy Zoom do wideoszkoleń i spotkań, która w marcu 2020 r. osiągnęła $200 \mathrm{mln}$ aktywnych użytkowników w porównaniu z $10 \mathrm{mln}$ w grudniu 2019 r. Było to oczywiście spowodowane przeniesieniem nauki w szkołach do przestrzeni internetowej, jak i rozpoczęciem pracy zdalnej w przedsiębiorstwach na całym świecie.

Chillakuri (2020) zauważa jeszcze jeden aspekt dotyczący adaptacji i wykorzystania nowych technologii, a mianowicie zmianę grupy docelowej. Do pracy przystępuje tzw. generacja Z. Według Lanier (2017) jest to grupa osób urodzonych po 1995 r. stanowiąca obecnie 32\% globalnej populacji. Generacja Z wyróżnia się od wcześniejszych tym, że jest pierwszą, która nie znała świata bez Internetu. Badania Chillakuri (2020) wskazują, że pracownicy z generacji Z oczekują wykorzystania nowych technologii podczas etapu adaptacji (onboardingu), gdyż jest to dla nich codzienność i są zaawansowani w jej wykorzystaniu. Dlatego zastosowanie kursów e-learningowych do samodzielnej nauki we własnym tempie, wideospotkania z wykorzystaniem platform do wideokonferencji zamiast zebrań stacjonarnych wskazują jako naturalne narzędzia pozyskiwania wiedzy i współpracy. 
Według raportu Glassdor 61\% pracowników stwierdziło, że rzeczywista praca, jaką mają wykonywać, różni się od tego, co im obiecywano podczas rekrutacji (Mackay, 2018). Dlatego tak ważny jest cały proces rekrutacji - od odpowiedniego zdefiniowania potrzeb po rekrutację, selekcję i adaptację.

\section{Podsumowanie}

W artykule przedstawiono istotę i ważność etapu adaptacji w procesie rekrutacji pracownika. Jego wpływ na dalszą pracę, satysfakcję i zaangażowanie został zbadany naukowo i jest niepodważalny. Postępująca transformacja cyfrowa oraz digitalizacja w przedsiębiorstwach sprawiły, że w tym procesie coraz częściej tradycyjne metody przekazywania wiedzy czy szkoleń są zastępowane przez metody e-learningowe. Zostały one wstępnie zdefiniowane przez autora, ale wymagają bliższej analizy i badań wśród przedsiębiorstw. Trwająca rewolucja cyfrowa została przyśpieszona przez panującą pandemię COVID-19 i zastosowanie nowych technologii zwiększyło się na nieprzewidzianą wcześniej skalę, co pokazują wyniki aktywności na platformach e-learningowych i do wideospotkań na całym świecie.

W związku z tym postulowane jest bliższe przeanalizowanie tematu i zbadanie następujących obszarów:

- zastosowanie e-learningu w procesie adaptacji nowych pracowników w czasach pandemii,

- analiza stosowanych narzędzi e-learningowych w procesie adaptacji przez przedsiębiorstwa,

- porównanie metod stacjonarnych z e-learningowymi w procesie adaptacji i ich wpływu na różne czynniki, jak: długość okresu osiągania samodzielności w pracy, stopień zaangażowania w pracę i funkcjonowanie firmy.

\section{Bibliografia}

Abramek, E. (2003). Wdrażanie idei „Organizacji samouczącej”. Systemy Wspomagania Organizacji. Katowice: Prace Naukowe/Akademia Ekonomiczna w Katowicach, 381-389.

Armstrong, M. (2005). Zarządzanie zasobami ludzkimi. Kraków: Oficyna Ekonomiczna. Bańka, W. (2002). Zarządzanie personelem w średniej i małej firmie. Toruń: Wydawnictwo Adam Marszałek. 
Bauer, T. (2010). Onboarding New Employees: Maximizing Success. https://www.shrm. org/foundation/ourwork/initiatives/resources-from-past-initiatives/Documents/ Onboarding\%20New\%20Employees.pdf, 11.04.2021.

Bayern, M. (2020). Enterprise eLearning: Uptick in Education Demand during Coronavirus Outbreak. https://www.techrepublic.com/article/enterprise-elearning-uptick-ineducation-demand-during-coronavirus-outbreak/, 6.03.2021.

Boushey, H., Glynn, S.J. (2012). There Are Significant Business Costs to Replacing Employees, Center for American Progress. https://www.americanprogress.org/wp-content/ uploads/2012/11/CostofTurnover.pdf, 6.03.2021.

Bugaj, J., Bugdol, M., Stańczyk, I. (2012). Procesy zarzq̨dzania zasobami ludzkimi w służbie zdrowia. Wrocław: Wydawnictwo Continuo.

Chillakuri, B. (2020). Understanding Generation Z Expectations for Effective Onboarding. Journal of Organizational Change Management, 33(7), 1277-1296.

Ciekanowski, Z. (2012). Proces adaptacji społeczno-zawodowej nowego pracownika. Zeszyty Naukowe Uniwersytetu Przyrodniczo-Humanistycznego w Siedlcach, 94, Seria: Administracja i Zarządzanie 21, 131-141.

Clarke, A. (2007). E-learning, nauka na odległość. Warszawa: Wydawnictwa Komunikacji i Łączności WKŁ.

Coursera (2019). Global Skills Index 2019. https://www.coursera.org/business/ebook/ gsi2019/, 12.11.2020.

Dąbrowski, M. (2013). E-learning w szkolnictwie wyższym. Nauka i Szkolnictwo Wyższe 3(35), 203-211.

Docebo (2016). E-learning Market Trends and Forecast 2017-2021. https://www.docebo. com/resource/elearning-market-trends-and-forecast-2017-2021/, 12.11.2020.

Docebo (2019). E-learning Trends. https://www.docebo.com/resource/report-elearning-trends-2019/, 12.11.2020.

Frączek, B. (2015). E-learning jako innowacyjna forma edukacji finansowej. Zeszyty Naukowe Uniwersytetu Ekonomicznego w Katowicach, 239, 36-50.

Gembalska-Kwiecień, A., Żurakowski, Z. (2016). System szkoleń i adaptacji pracowników w realizacji poprawy bezpieczeństwa pracy w kopalni. Zeszyty Naukowe Politechniki Śląskiej, Seria: Organizacja i Zarządzanie, 92, 85-94.

Global Workplace Analytics (2019). State of Telecommuting in the US. https://globalworkplaceanalytics.com/state-of-telecommuting-in-the-us, 12.11.2020.

Hirsch, A. (2007). Don't Underestimate the Importance of Good Onboarding. https://www. shrm.org/resourcesandtools/hr-topics/talent-acquisition/pages/dont-underestimatethe-importance-of-effective-onboarding.aspx, 12.11.2020.

Hyla, M. (2005). Przewodnik po e-learningu. Kraków: Oficyna Wydawnicza.

Iqbal, M. (2020). Zoom Revenue and Usage Statistics (2020). https://www.businessofapps. com/data/zoom-statistics/, 6.03.2021.

Jamka, B. (2001). Dobór zewnętrzny i wewnętrzny pracowników. Teoria i praktyka. Warszawa: Difin. 
Kałużny, R. (2018). Adaptacja nowych pracowników w organizacji. Edukacja dla Bezpieczeństwa, 1(38), 347-357.

Karney, J.E. (2007). Psychopedagogika pracy. Warszawa: Żak Wydawnictwo Akademickie. Kazenas, A. (2012). Organizacja procesu adaptacji zawodowej młodych pracowników. Bezpieczeństwo Pracy: Nauka i Praktyka, 3, 16-18. Warszawa: Centralny Instytut Ochrony Pracy - Państwowy Instytut Badawczy.

Kaźmierczak, M. (2017). Innowacje w procesie adaptacji pracowniczej. http://dspace.uni. lodz.pl:8080/xmlui/bitstream/handle/11089/23917/\%5B97\%5D-112\%20Innowacje\%20 w\%20procesie\%20adaptacji\%20pracowniczej.pdf?sequence=1\&isAll owed=y, 5.06.2020.

Kiliszewski, M. (2003). E-learning jako nowoczesny system zarządzania nauczaniem. W: M. Fertach, S. Trzcieliński (red.), Praktyka zarzadzania nowoczesnym przedsiebiorstwem. Poznań: Wydawnictwo Instytutu Inżynierii Zarządzania Politechniki Poznańskiej.

Kowalska, E. (2018). Gamifikacja w procesie adaptacji pracownika. http://wz.pcz.pl/znwz/ files/ZN\%20nr\%2031.pdf\#page=105, 17.10.2020.

Król, H., Ludwiczyński, A. (2014). Zarządzanie zasobami ludzkimi. Tworzenie kapitału ludzkiego organizacji. Warszawa: WN PWN.

Kubica, I. (2010). Adaptacja społeczno-zawodowa nowo przyjętych pracowników. Zeszyty Naukowe Uniwersytetu Ekonomicznego w Krakowie, 828, 37-50.

Linkedin (2020). Workplace Learning Report. https://learning.linkedin.com/content/ $\mathrm{dam} / \mathrm{me} /$ learning/resources/pdfs/LinkedIn-Learning-2020-Workplace-Learning-Report.pdf, 12.11.2020.

Listwan, T. (red.) (2006). Zarzq̨dzanie kadrami. Warszawa: C.H. Beck.

Ludwiczyński, A. (2006). Zarządzanie zasobami ludzkimi. Tworzenie kapitału ludzkiego organizacji. Warszawa: WN PWN.

Mackay, J. (2018). Work Expectations vs. Reality: What an Honest Job Description Would Look Like. https://blog.rescuetime.com/honest-job-description/, 11.04.2021.

Maliński, S. (1997). Program adaptacyjny, czyli „nowy” w nowym miejscu pracy. Personel, 4, 10-12.

ManaHR (2021). Jak wyglądała fluktuacja kadr w polskich firmach. https://raportplacowy. pl/blog/jak-wygladala-fluktuacja-kadr-w-polskich-firmach/, 11.04.2021.

Marciniak, J. (1997). Pierwsze kroki. Adaptacja zawodowa pracowników. Personel, 12.

Marciniak, J. (2013). Analiza i planowanie zatrudnienia. W: J. Marciniak (red.), Meritum HR. Warszawa: Wolters Kluwer.

Martyniak, Z. (1997). Elementy zarzq̨dzania informacjami i komunikacją w przedsiębiorstwie. Kraków: Wydawnictwo AE w Krakowie.

Mikuła, B., Ziębicki, B. (2003). Komunikacja wewnętrzna jako instrument nowo przyjętych pracowników (wyniki badań w firmach Polski Południowej). Zeszyty Naukowe Akademii Ekonomicznej w Krakowie, 626, 103-113.

Oleksyn, T. (2006). Zarzq̨dzanie kompetencjami: teoria i praktyka. Kraków: Oficyna Ekonomiczna. 
Olszak, C. (2007). Strategie i modele gospodarki elektronicznej. Warszawa: WN PWN.

Orczykowska, A. (2006). Proces budowy treści szkoleń e-learningowych. http://elearning. pl/filespace/artykuly/Orczykowska. pdf, 13.02.2021.

Plebańska, M., Kopciał, P. (2013). Platforma e-learningowa jako narzędzie zarządzania wiedzą. E-mentor, 2, 49.

Pocztowski, A. (2003). Zarzqdzanie zasobami ludzkimi. Warszawa: PWE.

Ratajczak, Z. (2007). Psychologia pracy i organizacji. Warszawa: WN PWN.

Sanocki, M., Wurst, T. (2021). E-learning W: Encyklopedia Zarzq̨dzania. https://mfiles. $\mathrm{pl} / \mathrm{pl} /$ index.php/E-learning, 13.02.2021.

Schwan, K., Seipel, K. (1995). Marketing kadrowy. Warszawa: C.H. Beck.

Small, T. (2009). Nauczanie na odległość (e-learning). Zeszyty Naukowe, Wyższa Szkoła Oficerska Wojsk Lądowych im. gen. T. Kościuszki we Wrocławiu, 3, 105-114.

Stein, M., Cristiansen, L. (2010). Successful Onboarding: Strategies to Unlock Hidden Value Within Your Organization. McGraw Hill Professional.

Syper-Jędrzejak, M. (2013). Dobre praktyki w zakresie adaptacji pracowników na przykładzie wybranych firm regionu łódzkiego. http://www.pim.wzr.pl/pim/2013_1_4_33. pdf, 17.10.2020, Zarzq̨dzanie i Finanse, 4(1), 495-508.

TenderHut (2018). Onboarding $w$ nowoczesnym wydaniu - co robić, żeby dobrze wprowadzić nowego pracownika?. https://infowire.pl/generic/release/383556/onboardingw-nowoczesnym-wydaniu-co-robic-zeby-dobrze-wprowadzic-noweg/, 17.10.2020.

Vien, C. (2007). Rethinking Retention. Journal of Accountancy. https://www.journalofaccountancy.com/issues/2017/may/rethinking-retention.html, 18.02.2021.

Woźniak, J. (2013). Rekrutacja. Teoria i praktyka. Warszawa: Wydawnictwa Profesjonalne PWN.

Woźniak, M. (2012). Kryteria i metody oceny efektywności szkoleń e-learningowych. Zeszyty Naukowe Małopolskiej Wyższej Szkoły Ekonomicznej w Tarnowie, 21(2), 183-186.

Zabiegliński, A. (2011). Intermentoring - wykorzystaj potencjat pracowniczy, prezentacja opracowana w ramach projektu Akademia Skutecznego Mentoringu, konferencja w Wiśle. http://trueit.nazwa.pl/intermentoring.org.pl/?page_id=161, 15.10.2011.

Zaleśna, A. (2015). Adaptacja nowego pracownika i wzajemne dzielenie się wiedzą na przykładzie przedsiębiorstw sektora MSP. Studia i Prace Wydziału Nauk Ekonomicznych o Zarządzania, 39(3), 411-424. https://wneiz.pl/nauka_wneiz/sip/sip392015/SiP-39-t3-411.pdf, 19.09.2020.

Ziębicki, B. (2003). Wykorzystanie komunikacji wewnętrznej do adaptacji nowo przyjętych pracowników, prezentacja wyników badań w firmach Polski południowej. Kraków: Akademia Ekonomiczna w Krakowie.

Żarczyńska-Dobiesz, A. (2008). Adaptacja nowego pracownika do pracy w przedsiębiorstwie. Kraków: Wolters Kluwer.

Żołędziewski, Ł. (2011). E-learning jako integralny element polityki personalnej przedsiębiorstw. Studia i Materiały Polskiego Stowarzyszenia Zarzq̨dzania Wiedzq/Studies \& Proceedings Polish Association for Knowledge Management, (57). 


\title{
Abstract \\ Characteristics of e-learning as an Instrument Supporting HR Activities in Adaptation of Employees
}

\begin{abstract}
Adaptation as one of the elements of the recruitment process is an important part of introducing an employee to a new organisation. The author decided to analyse the application of new technologies such as e-learning used in enterprises as an element of digital transformation and an answer to the expectations of new generations of employees.
\end{abstract}

Keywords: e-learning, adaptation, human resources management

\section{Mgr Mariusz Andreasik}

Doktorant w Instytucie Kapitału Ludzkiego Szkoły Głównej Handlowej w Warszawie. Główne zainteresowania badawcze to zastosowanie narzędzi e-learningowych w rozwoju zasobów ludzkich w przedsiębiorstwach, adaptacji nowych pracowników, motywacji, zarządzaniu wiedzą w organizacji.

e-mail: mandreasik@gmail.com

ORCID: 0000-0001-6903-0134 